Vol 9, No 1 (2021) | ISSN 2153-5914 (online) | DOI 10.5195/contemp/2021.330

http://contemporaneity.pitt.edu

\title{
Painting as a Modern Art in Early Renaissance Italy
}

Robert Brennan

Christopher J. Nygren

\section{Book Review}

Robert Brennan, Painting as a Modern Art in Early Renaissance Italy. London: Harvey Miller, Renovatio Artium Series in the Arts of the Renaissance, 2019. 366 pp; 11 b/w ills. + 115 color ills., $1 \mathrm{~b} / \mathrm{w}$ table. Hardcover $€ 125$

(9781912554003)

\section{About the Author}

Christopher J. Nygren is associate professor of the History of Art and Architecture at the University of Pittsburgh. His research focuses on the intersection of religion, philosophy, and art in the Italian Renaissance, and it has been featured in The Art Bulletin, Renaissance Quarterly, and other leading academic journals. His book, Titian's Icons: Tradition, Charisma, and Devotion in Renaissance Italy, was published by Penn State University Press in 2020. 


\section{Painting as a Modern Art in Early Renaissance Italy}

Robert Brennan

Christopher J. Nygren

"Claims to modernity," a recognizable genre of academic writing, generally seek to demonstrate that some constitutive element of the contemporary world has its origins submerged in the period the author studies. Over the last four years, the Genealogies of Modernity project has been dedicated to studying these sorts of claims. In that time, it has become clear that the term "modernity" has an irresistible appeal: "modernity talk" is ubiquitous. While the term "modern" has been used since the fifth century $\mathrm{CE}$, modernity is a much more recent coinage, first used in the nineteenth century. What space exists between historical actors trying to recognize the limits of their own "modern" moment and claims to an absolute "modernity"? Since I began training in the field of Italian Renaissance art history in the mid 2000s, claims to the "modernity" of Renaissance art have animated much of the most exciting work in the field, but they have also engendered responses from those who feel it is important to underline the Renaissance's "non-modernity."1

Robert Brennan's Painting as a Modern Art in Early Renaissance Italy shows a different path forward by avoiding claims to absolute modernity and instead revealing how the term "modern" operated in art criticism of the early Renaissance. Brennan is principally interested in reconstructing the discursive field in which Giotto's primacy was still provisional and subject to challenge. By the middle of the sixteenth century, Giotto had become a stand-in for the artistic revolution that was believed to have taken place around 1300 . Brennan looks to show how this came to be the case. Giotto's contemporaries certainly noted his prowess, and Dante memorably described how he had surpassed his teacher, Cimabue. ${ }^{2}$ But Dante saw in this episode a message about human vanity, not the emergence of modernity. By contrast, Brennan argues that, for authors writing around 1400, "the difference between Giotto and his predecessors came to be understood as the beginning of 'modern art'" (7).

The study unfolds over three lengthy chapters. The introduction sets up the problem of the book by beginning with Giorgio Vasari, who was unable to recognize the radical nature of the fifteenth-century critics he cited. Brennan demonstrates this by closely analyzing a passage in the Lives in which Vasari cites Cennino Cennini's Craftsman's Handbook. In Vasari's gloss, Cennini described Giotto as having "translated" the Greek manner into Latin, but as Brennan shows through the rest of the book, this version critically undersells Cennini's account.

Chapter one focuses on the theory, practice, and social contexts that informed Cennini's appraisal of Giotto's revolutionary position in the history of art. Cennini wrote his treatise around 1400 in Padua, and he made much of his artistic genealogy, which descended from Giotto via Taddeo (ca. 1290-1366) and Agnolo Gaddi (1350-1396). Essentially, the chapter aims to untangle the implications of a seemingly simple sentence embedded in the first chapter of Cennini's handbook: Giotto "changed the art of painting from Greek into Latin, and made it modern, and had the art more complete than anyone since (rimutò l'arte del dipignere di grecho in latino, e ridusse al moderno, e ebe l'arte più compiute ch'avessi mai più nessuno [sic. ])" (17). In this chapter, as elsewhere, Brennan's comfort with close reading carries the day. Brennan explores what Cennini meant when he said that Giotto "reduced to modern" (ridusse al moderno) the art of painting. Through philological concatenation, Brennan demonstrates that Giotto was understood not simply to have "translated" Greek style into

${ }^{1}$ For a discussion of these issues, see Stephen J. Campbell, "On Renaissance Nonmodernity," I Tatti Studies in the Italian Renaissance 20, no. 2 (2017): 261-94.

2 Purgatorio XI, 94-99. 
Latin, but also to have transmuted the style by simplifying or abbreviating painterly technique in such a way as to open a new pathway forward.

The upshot of this chapter is to show that for Cennini "to call [Giotto's] art 'modern' was to do something more than celebrate the new degree to which it could faithfully imitate outward appearances. It was to assert that the art now imitated nature inwardly, in its manner of operation, to an extent formerly impossible and never again to be superseded" (21). Brennan tracks the differences between Giotto's pictorial style and that of Byzantine icon painters by comparing Cennini's text to a late Byzantine treatise, probably written sometime around 1355. This comparison shows how the simplicity of Giotto's style made it imitable. In this period "art" was linked to the Greek concept of techne, a skill that can be taught. By reducing the complex procedures of Byzantine painters, Giotto did more than merely translate their style; he fundamentally transformed the style's grammar, simplifying it and making it more accessible. In this, according to Brennan, resides Cennini's account of how Giotto inaugurated pictorial modernity.

If chapter one traces Cennini's affirmative case for Giotto's modernity, chapter two takes a decidedly more jaundiced tone as it examines the biting irony embedded in the description of pictorial modernity provided by Franco Sacchetti in story 136 of the Trecentonovelle (ca. 1390). In the story, a group of painters and sculptors gathers for a raucous dinner at a local monastery. After finishing the meal and imbibing a copious amount of wine, the conversation turns to the question "[W]hich master of painting was greatest of all, aside from Giotto?" A few painters try their hand at answering the question, with mixed results, until they turn to sculptor Alberto (presumably modeled on the sculptor Alberto Arnoldi), who offers an assessment of "modern painters" (moderni dipintori). Alberto argues that "the women of Florence are the greatest masters of painting there have ever been because, as one clearly sees, they restore things where nature is deficient" (95). Cosmetics, rather than any theory of techne or "reduction," carries the day in Alberto's assessment.

Alberto's distasteful misogyny is rightly called out by the author, even as he seeks to understand the deeper, systemic logic that would lead an artist to make such a claim. This turns somewhat unexpectedly into a study of the repainting of icons-a "modern" cosmetic treatment of paintings made by antecedent generations. Brennan shows how, along a number of axes (skin color, complexion, and proportion), the retouching of icons not only made them look refreshed but also brought them in line with new standards of fashion and beauty. Skills that Alberto had signaled as the province of the women painters of Florence-the ability to make a crooked nose appear straight, for instance-are shown to be at the heart of these campaigns of pictorial renovation. Brennan's analysis of the repainting of medieval pictures to align with early Renaissance tastes leads into an extended section on how this novel understanding of pictorial style depends on the emergence of "fashion" (foggia) as a cultural phenomenon in the 1340 s, which has long been identified by scholars of costume as the crucial decade when "modern" attire emerged.

The final chapter of the study moves into the fifteenth century and examines some sources that are more familiar to non-specialists, including Leon Battista Alberti's treatise on painting. However, the bulk of the chapter is given over to a less renowned author, Michele Savonarola, grandfather of the preacher Girolamo Savonarola, who was burned at the stake in Florence 1498. Michele was court physician in Ferrara, where he wrote a treatise that included reflections on painting. Savonarola spent considerable time reflecting on the shortcomings of Giotto's art, which he located in lack of symmetry and proportion: for Savonarola, Giotto was great, but he lacked a structured understanding of the art of painting. He followed intuition rather than rules. By contrast, Savonarola and Alberti both offer systematic accounts of painting, Savonarola's focused on proportion and Alberti's on the development of one-point perspective. Even if Alberti and Savonarola suggest that Giotto is excluded from the most cutting-edge art of their time (i.e. "modern," of the moment), Brennan argues that they nevertheless continued the project of pictorial modernity begun by Giotto because they advanced "the process of setting the art on a new foundation in science and rationalizing its 
procedures accordingly" (262). Linear perspective was the fruit of that effort, as Brennan shows through an analysis of the paintings of Andrea Mantegna. "Cennini could not have imagined anything like it, and yet [perspective] perfectly satisfied the criteria for improvements intrinsic to his conception of art" (263). Subsequent generations-Alberti, Ghiberti, Filarete-eschewed claims to pictorial modernity. Why?

This question is addressed in the book's conclusion. One difficulty of "modernity talk" is that historical horizons are ever shifting: the philological definition of modernus simply means "of this moment," and that moment is constantly receding. The vertiginous scope of time snaps into focus with some "did you know?" facts: woolly mammoths still roamed the earth as the great pyramids were being created; Aristotle (385-323 BCE) is only slightly more distant from our present age (2021 CE) than he himself was distant from the Old Kingdom of Egypt, the "Age of the Pyramids" (2686-2181 BCE), about which he wrote in the Meterologica; when Vasari published his Lives in 1568, the death of Giotto (d. 1337) was more distant from him than the death of George Washington (d. 1799) is from us in 2021. What are we to take away from all this? Were the pyramids somehow more "modern" (of their moment) than mammoths? It may seem so because they are part of teleological narrative of technology and civilization that seems inexorable; but perhaps the only take away is that what counts as "modern" is always subjective. Whereas Cennini felt invested because he identified as part of Giotto's artistic heritage, by the time Vasari was writing, Giotto's contribution had been frozen in amber, as it were, and transformed into an artifact of history. For Vasari, the maniera moderna ("modern manner") began roughly with the generation of Leonardo da Vinci and Giorgione; Giotto may have done much to move forward the art of painting, but in Vasari's account he is anything but "modern." As Brennan notes, the conception of pictorial "modernity" that he analyzes in Cennini, Sacchetti, Savonarola, and Alberti "must be considered a structural precondition for Vasari's outlook" (292); but by the sixteenth century, the historical horizon had once again shifted, distinguishing Vasari's "modernity talk" from that of previous generations.

Brennan takes the argument in many unexpected directions in order to diverge from more traditional explanations for when and how painting became modern. His narration is thoroughly seated in the late fourteenth and early fifteenth centuries, so before printmaking opened up the problem of substitution and raised questions about what constitutes an original. Similarly, Brennan avoids repeating the pervasive narrative of the secularization of painting in the fifteenth century. Scholars like Charles Dempsey, Hans Belting, and Richard Goldthwaite all take different tacks on this argument, but each draws attention to how the increase in private ownership of paintings throughout the fifteenth century fostered an approach more amenable to poetic theory and mythological subjects. Such arguments are usually not rooted in sources describing this turn of events as "modern," and therefore it would be interesting to see Brennan address them more directly, as he so clearly demonstrates that some notion of "the modern" was salient for his sources.

The volume is extremely well produced. It is sumptuously illustrated with crisp color pictures. The prose flows, and all texts are translated in the main body text while footnotes contain the original language texts, allowing the reader to follow some of the more philological moments in the book's argument. However, this reader was left feeling that the book might have benefitted from a slightly different structure. The length of the chapters makes them unwieldy for use in the classroom, and one wonders if there was a way to make the book more accessible to nonspecialists.

Renaissance Italy has long been one of the major proving grounds for claims to modernity. Jacob Burckhardt memorably called Italians the "first-born among the sons of modern Europe," 
a claim that was, of course, freighted with all sorts of noxious nationalistic implications. ${ }^{3}$ What constitutes the "modernity" of the Italian Renaissance is constantly being revised, but Brennan's book reveals that scholars have become much more subtle, reasoned, and philological in the arguments they make, in large part because the claims he makes are not absolute claims about who is and is not modern. Rather, Brennan attempts to recover the "modernity talk" that was circulating in certain elite circles in Italy around 1400. Modernity, it seems, is evergreen. New articles in this journal are licensed under a Creative Commons Attribution 4.0 United States License.

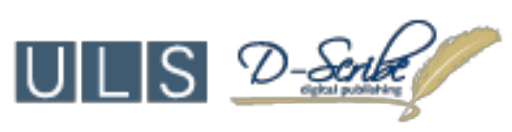

This journal is operated by the University Library System of the University of Pittsburgh as part of its D-Scribe Digital Publishing Program, and is co-sponsored by the University of Pittsburgh Press.

3 Jacob Burckhardt, The Civilization of the Renaissance in Italy (Oxford: Phaidon, 1950), 70. On the nationalistic implications of Burckhardt's argument for Germanic cultures, see Martin A. Ruehl, The Italian Renaissance in the German Historical Imagination, 18601930 (Cambridge: Cambridge University Press, 2015), esp. 1-104. 